ations for these entities, as will Republicans on the House Interior Committee and the House Appropriations Committee, the committees responsible for NEH and NEA funding.

Senate retirements have decreased the level of that body's support for NEH and NEA: ten of the fourteen senators who retired effective January 1997 were strong supporters. The report was more optimistic, however, about Senate support than House support. Senator Ted Stevens (R$\mathrm{AK}$ ), who strongly backs funding for the arts and humanities, will chair the Appropriations Committee, while Senator Slade Gordon (R-WA), also a strong backer, will continue to chair the Interior Subcommittee, whose membership has likewise demonstrated bipartisan support of such funding.

With President Clinton's promise to be the first president in decades to balance the Federal budget and his favorable attitude toward the Balanced Budget Amendment, the report warned that the Clinton administration's strong past support for NEH and NEA may not predict his level of support during the 105th Congress. By the same token, the report argued, Clinton may now feel more free in his second term to secure such funding.

"[T]he mounting pressures connected with balancing the budget are bound to present obstacles for NEH [and NEA]," the report argued. "As long as targets for reduction are maintained without reductions in the defense or entitlement budgets, it is going to be very difficult for federal activities such as NEH to thrive in the discretionary portion of the federal budget from which most of the savings will be found."

APSA is an active member of $\mathrm{NEH}$.

\section{Future of NSF Funding a Cause for Concern}

Neal Lane, director of the National Science Foundation, expressed worries about the future of his organization, saying NSF will have to "make tough decisions" in the next year. With projections of a $20 \%$ reduction in domestic spending, Lane fears many current projects of NSF will have to be abandoned.

Lane called upon members of the social, behavioral, and economic science community to organize in support of funding, and he asked the Coalition for National Science Funding (CNSF), an organization of 80 groups around the country, to continue efforts to advocate for funding.

Despite projected hard times, Lane stated that NSF will keep as their primary goals advancement of scientific discoveries and education. Beginning in Fiscal Year 1999, NSF will have to comply with the Government Performance Results Act (GPRA) and prepare an annual performance evaluation. Suggesting that NSF will focus more on qualitative goals and will adopt a peer review process for the evaluation of the Foundation's success, Lane sees these as ways to make the best case for government funds.

APSA is a member of CNSF.

\section{Adapted from "COSSA Washington Update"}

\section{Behavioral and Social Science Research Defined}

The Office of Behavioral and Social Science Research (OBSSR) at the National Institutes of Health has provided its official definition of behavioral and social science research, encompassing five key principles. Under their definition, behavioral and social science research (1) is theory-driven; (2) seeks to identify patterns of behavioral and social functions; (3) acknowledges the importance of life span perspective; (4) seeks to identify variation among and between different individuals, ethnicities, genders, age groups, and socioeconomic categories; and (5) is based in both social and biological contexts.

The OBSSR definition was developed with help from the National Institute of Mental Health, the National Institute of Alcohol Abuse and Alcoholism, and the National Research Council.

For the full text of OBSSR's ninepage document, access their home page at wwwl.od.nih.gov/obssr/ obssr.htm

\section{Trends in the Profession}

More than 915,000 faculty members were employed by higher education institutions in 1993, nearly double the 474,000 employed in 1970 , according to a report from the National Center for Education Statistics. Other findings:

- Nearly one third (32\%) of all faculty members were employed by two-year colleges in 1993, up from $26 \%$ in 1976 and $19 \%$ in 1970 . Since 1976 , the number of faculty at fouryear institutions increased $34 \%$, while the number at two-year colleges rose by $74 \%$.

- The percentage of faculty who worked part-time also has grown as shown in the following chart. Women faculty were more likely than men to be hired on a part-time basis. In 1993, women comprised one-third of all full-time faculty and $47 \%$ of those employed part-time. Overall, while only $35 \%$ of male faculty were parttime employees, almost half $(49 \%)$ of all female faculty were employed part-time.

- Between 1976 and 1993, the number of women faculty employed full-time increased by $70 \%$, while the number of women employed as parttime faculty rose by $163 \%$.

- From 1977 to 1993, minorities have grown as a proportion of the new hires of full-time faculty, growing from $10.9 \%$ in 1977 to $19.8 \%$ in 1993.

\section{Fall Staff in Postsecondary Institu-} tions, 1993 is $\$ 15$ from the Superintendent of Documents, U.S. Government Printing Office, Mail Stop

\section{Percentage of Higher Education Faculty Who} Were Employed Part Time, Selected Years

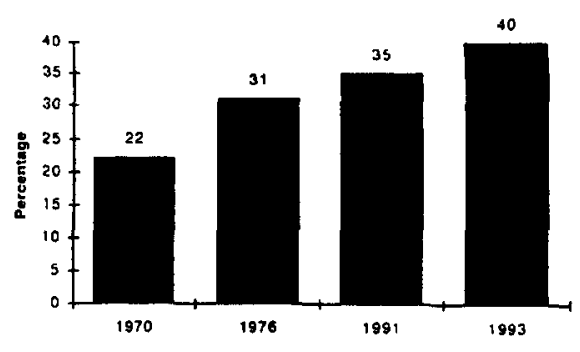

Source: U.S. Department of Education, National Center for Education Statistics. Fall Staff in Postsecondary Institutions, 1993. 1996. Copies of this publication (065-000-00871-8) are available for \$15 from the Superintendent of Documents. U.S. Government Printing Office. Mail Stop SSOP. Washington, DC 20402-9328. Telephone orders: (202) 512-1800. 